University of Nebraska - Lincoln

DigitalCommons@University of Nebraska - Lincoln

Comparison of Production, Meat Yield, and Meat Quality Traits of NWAC103 Line Channel Catfish, Norris Line Channel Catfish, and Female Channel Catfish $\times$ Male Blue Catfish $\mathrm{F}_{1}$ Hybrids

\author{
Brian G. Bosworth \\ USDA-ARS, bbosworth@ars.usda.gov \\ William R. Wolters \\ USDA-ARS \\ Juan L. Silva \\ Mississippi State University \\ Roberto S. Chamul \\ Mississippi State University \\ Sinyoung Park \\ Mississippi State University \\ Follow this and additional works at: https://digitalcommons.unl.edu/usdaarsfacpub \\ Part of the Agricultural Science Commons
}

Bosworth, Brian G.; Wolters, William R.; Silva, Juan L.; Chamul, Roberto S.; and Park, Sinyoung, "Comparison of Production, Meat Yield, and Meat Quality Traits of NWAC103 Line Channel Catfish, Norris Line Channel Catfish, and Female Channel Catfish $\times$ Male Blue Catfish $\mathrm{F}_{1}$ Hybrids" (2004). Publications from USDA-ARS / UNL Faculty. 521.

https://digitalcommons.unl.edu/usdaarsfacpub/521

This Article is brought to you for free and open access by the U.S. Department of Agriculture: Agricultural Research Service, Lincoln, Nebraska at DigitalCommons@University of Nebraska - Lincoln. It has been accepted for inclusion in Publications from USDA-ARS / UNL Faculty by an authorized administrator of DigitalCommons@University of Nebraska - Lincoln. 


\title{
Comparison of Production, Meat Yield, and Meat Quality Traits of NWAC103 Line Channel Catfish, Norris Line Channel Catfish, and Female Channel Catfish $\times$ Male Blue Catfish $\mathbf{F}_{1}$ Hybrids
}

\author{
Brian G. BoswORTH* AND William R. Wolters \\ USDA-ARS Catfish Genetics Research Unit, \\ Thad Cochran National Warmwater Aquaculture Center, \\ Post Office Box 38, Stoneville, Mississippi 38776, USA \\ Juan L. Silva, Roberto S. Chamul, and Sinyoung Park \\ Department of Food Science and Technology, Post Office Box 9805, Herzer Building, \\ Stone Boulevard, Mississippi State University, Starkville, Mississippi 39762, USA
}

\begin{abstract}
NWAC103 line channel catfish Ictalurus punctatus, Norris line channel catfish, and Norris line female channel catfish $\times$ Dycus Farm line male blue catfish $I$. furcatus $\mathrm{F}_{1}$ hybrids were compared for production, meat yield, and meat quality traits. Juvenile fish from each genetic group were stocked at 12,000 fish/ha into three, 0.04-ha ponds per genetic group. Fish were fed once daily to satiation from June through October, and fed on days when afternoon water temperatures were above $17^{\circ} \mathrm{C}$ from November through December. Fish were harvested, weighed, and counted in January, and 150 fish per genetic group (50 fish per pond) were processed and measured for meat and body component yield. Instrumental and sensory panel evaluations of quality were measured on fresh, frozen-thawed, and baked fillets. Stocking weight, harvest weight, and net production $(\mathrm{kg} / \mathrm{ha})$ were highest for the NWAC103 line channel catfish, intermediate for the hybrid, and lowest for the Norris line channel catfish. Growth at unit size $(a)$, percent weight gain, survival, and feed conversion were not significantly different among genetic groups. Carcass yield (relative to whole weight) and fillet yield were higher for the hybrid than for the two channel catfish lines, and higher for females than for males in all genetic groups. Head yield and total viscera yield were higher for the channel catfish lines than the hybrid. Head yield was higher for males than for females, and total viscera yield was higher for females than for males. Visceral fat yield was higher for the hybrid than for the two channel catfish lines. Instrumental and sensory panel analysis indicated only minor differences among genetic groups for fillet quality. Thus, catfish producers and processors can improve important traits and increase profits by utilizing catfish lines with superior performance.
\end{abstract}

Production traits (growth, feed conversion, and survival) and processing traits (meat yield and quality) are economically important traits of farmraised catfish, and improving these traits will benefit the catfish farming industry. Genetic improvement programs have resulted in substantial improvements in production and processing traits in other meat animal species, and similar improvements could be achieved in farm-raised catfish. Evaluation, identification, and use of superior germplasm from existing genetic resources could allow rapid improvements in the production and processing traits of farm-raised catfish. Part of the mission of the USDA-ARS Catfish Genetics Research Unit is to produce genetically superior germplasm for release to the catfish farming in-

* Corresponding author: bbosworth@ars.usda.gov

Received August 13, 2003; accepted January 14, 2004 dustry. The NWAC103 line of channel catfish Ictalurus punctatus (a line of catfish developed jointly between the USDA-ARS and Mississippi State University) is being compared with other genetic groups of catfish having potential commercial use. The objective of this study was to compare the NWAC103 line channel catfish, Norris line channel catfish (a line of fish currently being used by some commercial producers), and Norris line female channel catfish $\times$ Dycus Farm line male blue catfish I. furcatus $\mathrm{F}_{1}$ hybrids for production, meat yield, and meat quality traits.

\section{Methods}

Before stocking in ponds, fish from contemporaneous (all hatched within the same month), multiple full-sibling families within each genetic group were pooled after hatch and reared at similar densities (700-800 fish/ $\mathrm{m}^{3}$ ) in $750-\mathrm{L}$ fiberglass tanks supplied with flow-through well water (3.75- 
$\mathrm{L} / \mathrm{min}, 27^{\circ} \mathrm{C}$ ) and diffuse aeration. All spawns were produced in ponds, and males and females within each genetic group were allowed to mate at random. During the tank-rearing phase, all fish were fed the same commercial catfish fingerling diet to satiation daily, but data on feed consumption was not recorded. Juvenile fish from three tanks per genetic group were counted into samples of 100 fish, each sample was weighed to the nearest gram and stocked in June at 12,000 fish/ha into three, 0.04-ha ponds per genetic group. Fish were fed a $28 \%$ protein commercial catfish diet (Delta Western, Indianola, Mississippi) during the pondrearing phase. Fish were fed once daily to apparent satiation from June through October, and fed on days when afternoon water temperatures were above $17^{\circ} \mathrm{C}$ from November through December. The amount of feed delivered to each pond was recorded daily. Water temperature and dissolved oxygen were recorded daily, and emergency aeration was provided by an electric paddlewheel aerator when dissolved oxygen levels fell below 4.0 $\mathrm{mg} / \mathrm{L}$. Fish were harvested, counted, and weighed in January. Fish were counted into groups of 2530 fish and the total weight of groups (to the nearest $10 \mathrm{~g}$ ) was recorded. Because the weights of fish at pond stocking were different among genotypes, a growth rate index suggested by Jobling (1983) and modified for channel catfish (Silverstein et al. 1999) was also used to compare growth rates of the different genetic groups. This growth rate index $a$ was calculated using the following equation:

$$
\log _{e} G_{w}=a-0.371 \log _{e} W_{m}
$$

where $G_{w}$ is the specific growth rate in percent per day, $a$ is the intercept of the equation, -0.371 is a constant developed for channel catfish by Silverstein et al. (1999), and $W_{m}$ is the mean weight of fish in each pond ([pond stocking weight + pond harvest weight]/2). The intercept of this equation (a) allows the comparison of growth rate at unit size and has been suggested as an appropriate method for comparing the growth of fish with different initial weights (Jobling 1983; Silverstein et al. 1999).

Fifty fish weighing between 500 and $1,000 \mathrm{~g}$ were selected from each pond for processing. Fish selected for processing were killed by a percussive blow to the head, and each fish was implanted with a passive integrated transponder tag (Biomark, Meridian, Idaho) in the dorsal musculature to allow the identification of individual fish throughout processing. Fish were eviscerated by hand, deheaded, and filleted by machine (Barth Design, Buhl, Idaho), and fillets were skinned by machine (Collum Tool, Greenville, Mississippi). The data collected for each fish during processing included whole weight, sex, visceral fat weight, total viscera weight, head weight, carcass (skin on, head and viscera removed) weight, skin-on fillet weight, skin-off fillet weight, and skin weight (skin-on fillet weight—skin-off fillet weight). Fillet yield values were based on untrimmed fillet weight (a composite of shank fillet, nugget, rib bone, and pelvic/ pectoral fins). Ovary weight was measured for females. Yield (relative to whole weight) was determined for each component $(100 \times$ component weight/whole weight).

Fillets were placed in low-density polyethylene bags, held on ice overnight, and transported the next morning to the Department of Food Science, Mississippi State University, Starkville, Mississippi, for measurement of quality-related traits. Measurements were recorded on raw-fresh fillets (analyzed within $24 \mathrm{~h}$ of processing), frozenthawed fillets (frozen at $-18^{\circ} \mathrm{C}$ for 2 months, then thawed at $4^{\circ} \mathrm{C}$ for $24 \mathrm{~h}$ ), and baked fillets (frozen at $-18^{\circ} \mathrm{C}$ for 2 months, thawed at $4^{\circ} \mathrm{C}$ for $24 \mathrm{~h}$, and baked at $206^{\circ} \mathrm{C}$ for $30 \mathrm{~min}$ in an electrical range oven according to method 18.004 of the AOAC [1984]). Fresh (40 per genetic group), frozen-thawed (20 per genetic group), and baked (20 per genetic group) fillets were measured for instrumental color, $\mathrm{pH}$, and shear-compression force. A quantitative descriptive analysis method of sensory analysis (Stone and Sidel 1992) was used for sensory panel evaluations of frozenthawed and baked fillets.

Surface $\mathrm{pH}$ was measured on the anterior, middle, and posterior sections of the back (skin) side of fillets with a flat surface electrode, and the three readings were averaged for each fillet. Four grams of each fillet was homogenized in $36 \mathrm{~mL}$ of water for $30 \mathrm{~s}$ with a Brinkmann homogenizer (Brinkman Instruments Co., Westbury, New York), and the $\mathrm{pH}$ of the slurry was measured twice and averaged. An Accumet pH meter 925 (Fisher Scientific, Pittsburgh, Pennsylvania) was used to record $\mathrm{pH}$ values. A Hunter Labscan $6000 / 45^{\circ}$ spectrocolorimeter (Hunter Associates Laboratory, Reston, Virginia) was used to measure Hunter color values $\left(\mathrm{L}^{*}, \mathrm{a}^{*}, \mathrm{~b}^{*}\right)$ on the anterior, middle, and posterior portion of the outside (skin side) of fillets, and the color values for each fillet was the average of these three readings. Color was expressed as L* (light- 
TABLE 1.-Least square means $( \pm$ SE) for production traits of NWAC103 line channel catfish, Norris line channel catfish, and hybrids of channel catfish $\times$ blue catfish. Within a row, means followed by different letters are significantly different at $P<0.05$.

\begin{tabular}{lcccc}
\hline \multicolumn{1}{c}{ Variable } & NWAC103 & Norris & $\begin{array}{c}\text { Channel } \times \\
\text { blue hybrid }\end{array}$ & SE \\
\hline Stocking weight $(\mathrm{g})$ & $57 \mathrm{z}$ & $27 \mathrm{y}$ & $46 \mathrm{x}$ & 1.9 \\
Harvest weight $(\mathrm{g})$ & $655 \mathrm{z}$ & $389 \mathrm{y}$ & $503 \mathrm{x}$ & 32.7 \\
Net production (kg/ha) & $6125 \mathrm{z}$ & $3640 \mathrm{y}$ & $4701 \mathrm{x}$ & 434 \\
Percent weight gain (\%) & $1052.6 \mathrm{z}$ & $1345.4 \mathrm{z}$ & $997.3 \mathrm{z}$ & 113 \\
Intercept $(a)$ & $2.20 \mathrm{z}$ & $2.07 \mathrm{z}$ & $2.07 \mathrm{z}$ & 0.05 \\
Feed conversion ratio & $1.82 \mathrm{z}$ & $1.78 \mathrm{z}$ & $1.85 \mathrm{z}$ & 0.09 \\
Survival $(\%)$ & $94.6 \mathrm{z}$ & $89.8 \mathrm{z}$ & $91.5 \mathrm{z}$ & 2.5 \\
\hline
\end{tabular}

${ }^{\text {a }}$ Feed conversion ratio $=$ weight of food fed/weight gained.

ness), a* (redness + , greenness -), and $b^{*}$ (yellowness + , blueness - ).

A $\sim 50-\mathrm{g}$ piece was cut from the center portion of fillets and measured for shear and compression using an FTC model T-2100-CI texture meter equipped with a thin blade (CS-2) Krammer cell (Food Technology Corp., Rockville, Massachusetts). The texture meter crosshead speed was set at $100 \mathrm{~mm} / \mathrm{min}$ and the ram stroke at $300 \mathrm{~s}$. Compression force was calculated as the slope of a line drawn as the tangent of the shear curve from the texture graph.

A $15-\mathrm{cm}$ line scale was used to quantify the responses of a five-member sensory panel evaluating the sensory attributes of frozen-thawed and baked fillets. Frozen-thawed fillets were evaluated for color (white to red), firmness (soft-mushy to tough), and odor intensity (none to strong). Baked fillets were evaluated for color (brown to white), flakiness (not flaky to very flaky), firmness (softmushy to tough), flavor intensity (none-bland to sweet-nutty). Frozen-thawed and baked fillets were evaluated for overall acceptability on a hedonic scale from 1 to 9 , where 1 represented "like extremely," 5 represented "neither like or dislike," and 9 represented "extreme dislike" (Pigott 1988).

Stocking weight, harvest weight, net production ( $\mathrm{kg} / \mathrm{ha}), a$, percent weight increase, feed conversion ratio $(\mathrm{FCR}=$ weight of food fed/weight gained), and survival were analyzed with a oneway analysis of variance (ANOVA), with genetic group as a fixed effect and pond within genetic group as a random effect. Pond was the experimental unit and pond within genetic group mean square was used as the error term in tests of differences among genetic group means. Yield traits were analyzed as a split-plot ANOVA, with genetic group as a fixed effect whole plot factor; sex as a fixed-effect, split-plot factor; whole weight as a covariate; and sex-by-pond-within-geneticgroup interaction and pond within genetic group as random effects. Pond was considered the experimental unit for meat yield traits, sex-by-pondwithin-genetic-group interaction mean square was used as the error term in tests of differences among sexes, and pond-within-genetic-group mean square error was used as the error term in tests of differences among genetic groups for meat yield traits. Fillet quality traits were analyzed with a one-way ANOVA, with fish as the experimental unit and fish-within-genetic-group mean square error used as the error term in tests of differences among genetic groups. Statistical analysis was done using the mixed procedure of SAS (Statistical Analysis System, Cary, North Carolina). Differences among fixed effects were declared significant at $P<0.05$. A macro written for Proc Mixed (Pdmix 800, Arnold M. Saxton, University of Tennessee) was used to conduct multiple-range tests on genetic group means.

\section{Results}

Stocking weight, harvest weight, and net production were highest for the NWAC103 line channel catfish $(57 \mathrm{~g}, 655 \mathrm{~g}$, and $6126 \mathrm{~kg} / \mathrm{ha}$, respectively), intermediate for the channel catfish $\times$ blue catfish hybrids (46 g, $503 \mathrm{~g}$, and $4702 \mathrm{~kg} / \mathrm{ha}$, respectively), and lowest for the Norris line channel catfish $(27 \mathrm{~g}, 389 \mathrm{~g}$, and $3640 \mathrm{~kg} / \mathrm{ha}$, respectively; Table 1). The $a$ values, percent weight gain, survival, and FCR were not different among genetic groups (means for genetic groups pooled $=2.12$, $1,131.8 \%, 92.0 \%$, and 1.82 , respectively).

Results for yield of meat and other body components are presented in Table 2 . The channel catfish $\times$ blue catfish hybrid had higher carcass yield, skin-on fillet yield, and skin-off fillet yield than the NWAC103 and Norris line channel catfish. Females had higher carcass yield, skin-on fillet yield, 
TABLE 2.-Least square means $( \pm \mathrm{SE}$ ) for meat and body composition yield traits for NWAC103 line channel catfish, Norris line channel catfish, and channel catfish $\times$ blue catfish hybrids. Within a row, means followed by different letters are significantly different at $P<0.05$.

\begin{tabular}{|c|c|c|c|c|c|c|c|c|}
\hline \multirow[b]{2}{*}{ Trait } & \multicolumn{2}{|c|}{ NWAC103 } & \multicolumn{2}{|c|}{ Norris } & \multicolumn{2}{|c|}{ Channel $\times$ blue hybrid } & \multirow[b]{2}{*}{ SE } & \multirow{2}{*}{$\begin{array}{l}\text { Significant } \\
\text { effect }^{\mathrm{a}}\end{array}$} \\
\hline & Female & Male & Female & Male & Female & Male & & \\
\hline Total weight (g) & $708.2 \mathrm{z}$ & $786.9 \mathrm{y}$ & $562.9 \times$ & $603.1 \mathrm{wx}$ & $621.7 \mathrm{w}$ & $615.8 \mathrm{wx}$ & 24.9 & $\mathrm{G}, \mathrm{S}, \mathrm{S} * \mathrm{G}$ \\
\hline Head $(\%)$ & $22.9 \mathrm{z}$ & $25.0 \mathrm{y}$ & $22.7 \mathrm{z}$ & $25.6 \mathrm{y}$ & $20.8 \times$ & $21.6 \mathrm{w}$ & 0.22 & $\mathrm{G}, \mathrm{S}, \mathrm{S} * \mathrm{G}$ \\
\hline Viscera $(\%)$ & $12.7 \mathrm{zW}$ & $11.9 \mathrm{zy}$ & $13.0 \mathrm{wV}$ & $11.0 \mathrm{x}$ & 11.7 xy & 11.7 xy & 0.33 & $\mathrm{G}, \mathrm{S} * \mathrm{G}$ \\
\hline Carcass (\%) & $64.4 \mathrm{z}$ & $63.1 \mathrm{w}$ & $64.4 \mathrm{z}$ & $63.4 \mathrm{w}$ & $67.6 \mathrm{x}$ & $66.7 \mathrm{y}$ & 0.36 & $\mathrm{G}, \mathrm{S}$ \\
\hline Skin-on-fillet (\%) & $51.5 \mathrm{z}$ & $50.2 \mathrm{w}$ & $51.3 \mathrm{z}$ & $50.5 \mathrm{zW}$ & $54.1 \mathrm{x}$ & $53.3 \mathrm{y}$ & 0.32 & $\mathrm{G}, \mathrm{S}$ \\
\hline Skinned fillet (\%) & $45.9 \mathrm{z}$ & $44.6 \mathrm{w}$ & $45.7 \mathrm{zW}$ & $45.3 \mathrm{zW}$ & $48.3 x$ & $47.5 \mathrm{y}$ & 0.38 & $\mathrm{G}, \mathrm{S}$ \\
\hline Visceral fat (\%) & $1.6 \mathrm{z}$ & $1.5 \mathrm{z}$ & $1.5 \mathrm{z}$ & $1.3 \mathrm{z}$ & $3.3 \mathrm{x}$ & $3.6 \mathrm{y}$ & 0.13 & G \\
\hline Skin $(\%)$ & $5.6 \mathrm{zy}$ & $5.6 \mathrm{zy}$ & $5.6 \mathrm{zy}$ & $5.3 \mathrm{y}$ & $5.8 \mathrm{z}$ & $5.8 \mathrm{z}$ & 0.15 & G \\
\hline Ovary (\%) & $1.2 \mathrm{z}$ & & $2.1 \mathrm{y}$ & & $0.3 \mathrm{x}$ & & 0.15 & G \\
\hline
\end{tabular}

${ }^{a} \mathrm{G}, \mathrm{S}$, and $\mathrm{S}^{*} \mathrm{G}$ indicate significant effects of genetic group, sex, and sex $\times$ genetic group interaction, respectively.

and skin-off fillet yield than males. Channel catfish lines had greater head yield than the hybrid, and males had greater head yield than females in all genetic groups. A significant sex $\times$ genetic group interaction indicated that the differences between sexes for head yield was more pronounced in the channel catfish lines than in the hybrid. Total viscera yield was higher for the channel catfish lines than for the hybrid. A significant sex $\times$ genetic group interaction for viscera yield was due to the percent viscera being higher for females than males in channel catfish lines, but not different among sexes in the hybrid. The hybrid had higher visceral fat yield than the NWAC103 and Norris line channel catfish. Ovary yield was highest for the Norris line channel catfish females $(2.1 \%)$, intermediate for the NWAC103 line channel catfish females $(1.2 \%)$, and lowest for the hybrids $(0.3 \%)$.

Instrumental analysis of fresh, frozen-thawed, and baked fillets indicated significant, but minor, differences among genetic groups for fillet Hunter color values, $\mathrm{pH}$, and Krammer shear and compression force (Table 3). There were no clear patterns of differences among genetic groups for quality traits across fillet types (i.e., Norris line fillets had the lowest Krammer shear values as fresh fillets, but the highest shear values as baked fillets). Sensory panelists reported little differences among genetic groups for frozen-thawed fillets (Table 4). Sensory panelists reported inferior (higher score) overall acceptance for baked hybrid fillets compared with baked fillets from channel catfish lines, but panelists did not indicate differences among baked fillets for any of the other quality traits scored.

\section{Discussion}

The growth superiority of NWAC103 line channel catfish compared with Norris line channel cat- fish observed in earthen ponds in this study has been reported in tank and pond trials (Silverstein et al. 1999; Jackson et al. 2003). The NWAC103 channel catfish line typically has superior growth compared with other channel catfish lines ( $\mathrm{Li}$ et al. 1998; Li et al. 2001). NWAC103 line channel catfish were larger at stocking and harvest, and had higher net production than hybrids in this study, in contrast to reports by $\mathrm{Li}$ et al. (in press) that channel catfish $\times$ blue catfish hybrids grew faster and had higher net production than NWAC103 line channel catfish. Inconsistencies among studies for growth comparisons of channel catfish lines and channel catfish $\times$ blue catfish hybrids may be due to differences in the parental stocks of channel catfish and blue catfish used to produce hybrids. In the current study, the Norris line channel catfish was used to produce the hybrid, while in the $\mathrm{Li}$ et al. (in press) study a commercial line of channel catfish selected for fast growth was used to produce the hybrid. Performance of the hybrid can differ depending on the pure species parental line used.

Although there were differences among genetic groups for stocking and harvest weight, there were no differences in $a$ values (a measure of growth rate adjusted for initial size differences). Although the $a$ values for NWAC103 line catfish were numerically higher (2.20) than the other two genetic groups (2.07) and approached significance $(p=$ 0.12 ), the data indicated the main difference in growth among genetic groups was during the tank phase. Adjustments for differences in starting weights in animal growth studies can be problematic (Hopkins 1992) and misleading if animals with faster early growth are penalized for their superior early growth. In the present study, all genetic groups were reared under similar conditions 
TABLE 3.-Least square means $( \pm \mathrm{SE}$ ) for instrumental quality variables for fresh, frozen-thawed, and baked fillets from NWAC103 line channel catfish, Norris line channel catfish, and channel catfish $\times$ blue catfish hybrids. Within a row, means with different letters are significantly different at $P<0.05$.

\begin{tabular}{|c|c|c|c|c|}
\hline Instrumental quality variables & NWAC103 & Norris & $\begin{array}{c}\text { Channel } \times \text { blue } \\
\text { hybrid }\end{array}$ & SE \\
\hline \multicolumn{5}{|c|}{ Fresh fillet } \\
\hline \multicolumn{5}{|l|}{ Color } \\
\hline $\mathrm{L}^{* \mathrm{a}}$ & 73.92 zy & $75.31 \mathrm{z}$ & $72.06 \mathrm{y}$ & 0.84 \\
\hline$a * b$ & $8.35 \mathrm{z}$ & $8.81 \mathrm{zy}$ & $9.25 \mathrm{zy}$ & 0.23 \\
\hline$b^{* c}$ & $22.01 \mathrm{z}$ & $25.74 \mathrm{y}$ & $22.75 \mathrm{z}$ & 0.58 \\
\hline Surface $\mathrm{pH}$ & $6.39 \mathrm{z}$ & $6.42 \mathrm{z}$ & $6.52 \mathrm{y}$ & 0.015 \\
\hline Ground sample $\mathrm{pH}$ & $6.39 \mathrm{z}$ & $6.33 \mathrm{y}$ & $6.36 \mathrm{y}$ & 0.01 \\
\hline Krammer shear force $(\mathrm{N})$ & $30.70 \mathrm{z}$ & 29.76 y & $33.40 \mathrm{x}$ & 0.58 \\
\hline Krammer compression force $(\mathrm{N})$ & $3020 \mathrm{z}$ & $2640 \mathrm{y}$ & $2440 \mathrm{x}$ & 85 \\
\hline \multicolumn{5}{|c|}{ Frozen-thawed fillets } \\
\hline \multicolumn{5}{|l|}{ Color } \\
\hline $\mathrm{L}^{*}$ & $59.51 \mathrm{z}$ & $62.22 \mathrm{z}$ & $58.94 \mathrm{z}$ & 2.28 \\
\hline $\mathrm{a}^{*}$ & $4.60 \mathrm{z}$ & $4.41 \mathrm{z}$ & $5.72 \mathrm{z}$ & 0.67 \\
\hline $\mathrm{b}^{*}$ & $15.02 \mathrm{z}$ & $16.94 \mathrm{z}$ & $15.38 \mathrm{z}$ & 1.72 \\
\hline Surface $\mathrm{pH}$ & $6.56 \mathrm{z}$ & $6.68 \mathrm{z}$ & $6.80 \mathrm{z}$ & 0.17 \\
\hline Ground sample $\mathrm{pH}$ & $6.58 \mathrm{zy}$ & $6.56 \mathrm{z}$ & $6.64 \mathrm{y}$ & 0.04 \\
\hline Krammer shear force $(\mathrm{N})$ & $39.05 \mathrm{z}$ & $36.05 \mathrm{z}$ & $43.80 \mathrm{z}$ & 4.32 \\
\hline Krammer compression force $(\mathrm{N})$ & $3395 \mathrm{z}$ & $2900 \mathrm{z}$ & $4225 \mathrm{z}$ & 700 \\
\hline \multicolumn{5}{|c|}{ Baked fillets } \\
\hline \multicolumn{5}{|l|}{ Color } \\
\hline $\mathrm{L}^{*}$ & $70.63 \mathrm{z}$ & $74.06 \mathrm{y}$ & $69.85 \mathrm{z}$ & 1.11 \\
\hline$a^{*}$ & $-1.21 \mathrm{z}$ & $-1.69 \mathrm{y}$ & $-1.26 \mathrm{z}$ & 0.18 \\
\hline $\mathrm{b}^{*}$ & $17.83 \mathrm{z}$ & $17.92 \mathrm{z}$ & $17.40 \mathrm{z}$ & 0.48 \\
\hline Surface $\mathrm{pH}$ & $6.83 \mathrm{zy}$ & $6.73 \mathrm{z}$ & $6.87 \mathrm{y}$ & 0.06 \\
\hline Ground sample $\mathrm{pH}$ & $6.73 \mathrm{z}$ & $6.72 \mathrm{y}$ & $6.80 \mathrm{z}$ & 0.50 \\
\hline Krammer shear force $(\mathrm{N})$ & $12.87 \mathrm{z}$ & $16.31 \mathrm{y}$ & $11.63 \mathrm{z}$ & 0.95 \\
\hline Krammer compression force $(\mathrm{N})$ & $825 \mathrm{z}$ & $1280 \mathrm{y}$ & $680 \mathrm{z}$ & 190 \\
\hline
\end{tabular}

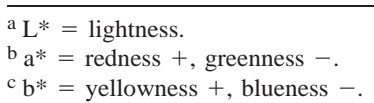

prior to pond stocking (same water source and flow rates, similar stocking densities, hatching dates, feed, and feeding rates), and initial size differences appear to have a genetic basis. In addition, the superior early growth of NWAC 103 relative to oth- er catfish lines has been reported previously ( $\mathrm{Li}$ et al. 1998; Silverstein et al. 1999). Commercial catfish producers are typically more concerned with days to a certain weight than percent weight increase during a given time. Therefore, from a pro-

TABLE 4.- - Least square means $( \pm$ SE) for sensory panel evaluations frozen-thawed and baked fillets from NWAC103 line channel catfish, Norris line channel catfish, and channel catfish $\times$ blue catfish hybrids. Within a row, means with different letters are significantly different at $P<0.05$.

\begin{tabular}{|c|c|c|c|c|}
\hline Characteristic & NWAC103 & Norris & $\begin{array}{c}\text { Channel } \times \text { blue } \\
\text { hybrid }\end{array}$ & SE \\
\hline \multicolumn{5}{|c|}{ Frozen-thawed fillets } \\
\hline Color & $8.69 \mathrm{z}$ & $9.77 \mathrm{z}$ & $7.19 \mathrm{y}$ & 0.64 \\
\hline Firmness & $5.85 \mathrm{zy}$ & $5.97 \mathrm{z}$ & $5.05 \mathrm{y}$ & 0.45 \\
\hline Odor intensity & $6.90 \mathrm{z}$ & $6.44 \mathrm{z}$ & $6.13 \mathrm{z}$ & 0.53 \\
\hline Overall acceptability & $4.24 \mathrm{z}$ & $4.15 \mathrm{z}$ & $4.44 \mathrm{z}$ & 1.70 \\
\hline \multicolumn{5}{|c|}{ Baked fillets } \\
\hline Color & $8.37 \mathrm{z}$ & $9.22 \mathrm{z}$ & $8.08 \mathrm{z}$ & 0.61 \\
\hline Flakiness & $8.88 \mathrm{z}$ & $8.70 \mathrm{z}$ & $8.19 \mathrm{z}$ & 0.42 \\
\hline Firmness & $7.13 \mathrm{z}$ & $6.75 \mathrm{z}$ & $6.66 \mathrm{z}$ & 0.44 \\
\hline Taste & $7.46 \mathrm{z}$ & $6.68 \mathrm{z}$ & $6.79 \mathrm{z}$ & 0.71 \\
\hline Overall acceptability & $3.90 \mathrm{z}$ & $3.95 \mathrm{z}$ & $4.22 \mathrm{y}$ & 0.13 \\
\hline
\end{tabular}


ducer's viewpoint, the NWAC103 line channel catfish had superior early growth and maintained that growth advantage throughout the production cycle. The early growth advantage of NWAC103 line catfish would be particularly beneficial to fingerling producers.

Survival during this study was good $(>89 \%)$ in all genetic groups. In studies with survival this high, it is difficult to make any conclusions about the relative merit of the genetic groups for survival since there did not appear to be any significant disease or management-related issues that impacted fish health.

We did not observe any differences among genetic groups for FCR. The growth superiority of NWAC103 relative to other channel catfish lines is generally attributed to their increased feed consumption (Li et al. 1998; Li et al. 2001), but other studies have reported increased feed consumption and improved FCR in NWAC103 line channel catfish (Silverstein et al. 1999; Jackson et al. 2003). While NWAC103 line channel catfish and the hybrid used in this study had similar FCR, Li et al. (in press) reported that channel catfish $\times$ blue catfish hybrids had a better FCR than NWAC103 line channel catfish. Discrepancies among studies may be related to differences in the lines of parental species used to produce the hybrids.

The superior carcass yield of the hybrid compared with that of the purebred channel catfish observed in this study has been reported previously (Argue 1996; Li et al. in press). Fillet yield was higher for the hybrid than for the channel catfish lines in this study, but fillet yield reported in this study was based on untrimmed fillet weight (including shank fillet, nugget, rib bone, and pectoral-pelvic fins). Li et al. (in press) reported that the hybrid used in their study had higher nugget yield than NWAC103 line channel catfish, but shank fillet yield (the higher value product) was not different between groups. Unpublished data from commercial processing plants also indicate that the higher meat yield of hybrids relative to channel catfish is primarily due to increased nugget yield. The higher carcass and fillet yield for females compared with males observed in this study is consistent with a previous study (Bosworth et al. 2001).

The meat yield analysis presented in this study compares genetic groups based on yield relative to whole weight. Catfish processors typically buy fish based on whole weight at a common price per unit whole weight. Therefore, meat yield relative to whole weight has a significant impact on pro- cessor profits. However, some large producers also process fish; in that situation the total weight of fillets produced per acre, per unit time would also be economically important. In the situation of an integrated producer-processor, the greater production per hectare of the NWAC103 would be advantageous since the NWAC103s would produce a greater "meat yield" in terms of the absolute weight of fillets produced per ha in a given unit time. However, for ease of interpretation, we have assumed the situation where processors are buying fish from producers at a constant price per unit weight, and therefore meat yield relative to whole weight is the trait of interest.

The differences among genetic groups, between males and females, and the genetic group $\times$ sex interactions observed for some yield traits in this study are likely related to differences in sexual maturation and gonad development among groups. It is important to remember when interpreting body component yield that a change in the yield of one component will affect the yield of other components since, by definition, they are all proportional to total weight and sum to $100 \%$. Development of secondary sexual characteristics associated with the maturation process in channel catfish include an increase in head size in males and an increase of ovary weight in females (Dunham et al. 1985). Argue (1996) reported reduced gonad development, poor fertility, and lesser development of secondary sexual characteristics in male and female channel catfish $\times$ blue catfish hybrids compared with channel catfish. The differences between genetic groups for body component yield (higher carcass yield, lower head yield, and lower ovary yield in the hybrid versus channel catfish) and the sex $\times$ genetic group interactions (differences in head and visceral yield between sexes less for hybrids than channel catfish) appear to reflect differences among genetic groups and sexes related to maturation and the development of secondary sexual characteristics. The higher visceral fat yield observed for the hybrid compared with channel catfish in this study was also reported by Li et al. (in press). Visceral fat is used as an energy store for gonad development in other fish species (Love 1970; Shul'man 1974), and it is possible the lower visceral fat stores in channel catfish were a result of energy from these stores being utilized in the maturation-gonad development process. A better understanding of the relationships among yield traits for various body components will be useful in designing breeding programs to improve meat yield. 
The body composition and processing trait data may have been influenced by the nonrandom selection of fish used for processing. In order to be relevant to commercial processors, it was necessary to select fish for processing that were of marketable weight rather than randomly selecting fish. In particular, because of their smaller harvest weight, fish processed from the Norris line were among the largest fish in that group, while NWAC103s and hybrids used for processing were from a more randomly selected group. Although whole weight was used as a covariate in the analysis of processing traits and body composition, it is still possible that the genetic group means for these traits reflect differences in the developmental stage of the proportion of the population selected for processing.

Sensory panel and instrumental evaluation of fillet quality variables indicated that there were statistically significant differences in $\mathrm{pH}$, color, and shear-compression force values among genetic groups. However, the differences were small, and a lack of consistent patterns indicating that one genetic group was superior for several quality traits makes interpretation of the data difficult. The sensory panel indicated that the overall acceptance of baked hybrid fillets was slightly poorer (higher score) than channel catfish lines, but there were no differences among genetic groups for individual quality traits of baked fillets (color, firmness, flakiness, and taste). A better understanding of the effects of genetics and environmental factors influencing meat quality in farm-raised catfish is needed.

In summary the NWAC103 line of channel catfish were larger at stocking and harvest and had higher production than the Norris line channel catfish and the channel catfish $\times$ blue catfish hybrid used in this study. The hybrid had a higher meat yield than the NWAC103 and Norris lines of channel catfish, and differences in meat yield among genetic groups and between sexes may be related to the maturation process and the development of secondary sexual characteristics. The NWAC103 line channel catfish would provide producers with increased production, while the channel catfish $\times$ blue catfish hybrid would provide higher meat yield to processors.

\section{References}

AOAC (Association of Official Analytical Chemists). 1984. Official Methods of Analysis, 14th edition. AOAC, Washington, D. C.
Argue, B. J. 1996. Performance of Channel Catfish Ictalurus punctatus, Blue Catfish I. furcatus, and Their $\mathrm{F}_{1}, \mathrm{~F}_{2}, \mathrm{~F}_{3}$ and Backcross Hybrids. Doctoral dissertation, Auburn University, Auburn, Alabama.

Bosworth, B. G., M. Holland, and B. L. Brazil. 2001. Evaluation of ultrasound imagery and body shape to predict carcass yield in farm-raised catfish. Journal of Animal Science 79:1483-1490.

Dunham, R. A., J. A. Joyce, K. Bondari, and S. P. Malvestuto. 1985. Evaluation of body conformation, composition, and density as traits for indirect selection for dress-out percentage of channel catfish. Progressive Fish-Culturist 47:169-175.

Hopkins, K. D. 1992. Reporting fish growth: a review of the basics. Journal of the World Aquaculture Society 23:173-179.

Jackson, S. L., E. H. Robinson, M. H. Li, W. R. Wolters, and D. A. McKee. 2003. Restricted and satiate feeding of two genetically isolated strains of juvenile channel catfish Ictalurus punctatus reared on $28 \%$ and $32 \%$ protein diets. Journal of the World Aquaculture Society 34:478-486.

Jobling, M. 1983. Growth studies with fish-overcoming the problems of size variation. Journal of fish Biology 22:153-157.

Li, M. H., E. H. Robinson, and B. B. Manning, B. G. Bosworth, W. R. Wolters. 2001. Comparison of growth, processing yield, and body composition of USDA103 and Mississippi "normal" strains of channel catfish Ictalurus punctatus fed diets containing three concentrations of protein. Journal of the World Aquaculture Society 32:402-408.

Li, M. H., E. H. Robinson, B. B. Manning, D. R. Yant, N. G. Chatakondi, B. G. Bosworth, and W. R. Wolters. In press. Comparison of the channel catfish, Ictalurus punctatus (NWAC103 strain) and the channel $\times$ blue catfish $I$. punctatus $\times I$. furcatus $\mathrm{F}_{1}$ hybrid for growth, geed efficiency, processing yield, and body composition. Journal of Applied Aquaculture.

Li, M. H., E. H. Robinson, and W. R. Wolters. 1998. Evaluation of three strains of channel Catfish Ictalurus punctatus fed three concentrations of protein and digestible energy. Journal of the World Aquaculture Society 29:155-168.

Love, A. H. 1970. The chemical biology of fishes. Academic Press, London.

Pigott, J. R. 1988. Sensory Analysis of Foods. 2nd editon. Elsevier Applied Science, London.

Shul'man, G. E. 1974. Life cycles of fish. Academic Press, London.

Silverstein, J. T., W. R. Wolters, and M. Holland. 1999. Evidence of differences in growth and food intake regulation in different genetic strains of channel catfish. Journal of Fish Biology 54:607-615.

Stone, H., and J. L. Sidel. 1992. Sensory Evaluation Practices, 2nd edition. Academic Press, San Diego. 